\title{
Rundt om idrætsfotografiet
}

Af Kim Furdal

\section{Indledning}

Det er ikke helt forkert, når det er blevet hævdet, at vi befinder os i en kommunikationsmæssig middelalder, hvor billedmediet spiller en stadig større rolle. Egentlig er det lidt af et paradoks. Fra slutningen af 1950'erne er produktionen af billeder vokset med den stigende velfærd, og med introduktionen af det digitale kamera er der formentlig tale om en billedmæssig eksplosion af hidtil ukendt omfang. Samtidig forbruges billeder i voksende tempo. Billeder bliver stadig mere påtrængende ikke blot $\mathrm{i}$ aviser og magasiner, i TV og PC, men også i byens rum. Fotografiet er blevet konsum, der skabes, forbruges og smides væk. Og så midt i dette billedbombardement er teksten stadig den bærende bestanddel af den gennemsnitlige hjemmeside. ${ }^{1}$ Det hurtigst voksende kommunikationsmedie er altså stadig bundet til teksten som udtryksform.

Vender vi for et $\varnothing$ jeblik blikket indad mod vores egen verden i Danmark, fylder billeder generelt en langt større andel af de historiske udgivelser end for blot 30 til 40 år siden. Syd for grænsen er forholdet anderledes. Her betragter man nærmest billedmediet som en intimidering af udgivelsens videnskabelige kvaliteter. I alt fald er billeder meget ofte fraværende i tyske historiske publikationer. Men desuagtet er billeder yderst sjældent en integreret del af den historiske analyse. De er oftest illustrationer og et kommercielt trækplaster, der kommer ind i den afsluttende redigeringsfase, hvor manuskript bliver til bog. I den forstand forbliver billederne et vedhæng, og teksten kunne ofte i bedste tysk tradition stå uden illustrationer. Hans Bonde er i den henseende en af meget få historikere, der eksplicit har fors $\varnothing \mathrm{gt}$ at bruge billedmediet som en del af den videnskabelige analyse og med god grund. Dybest set er det absurd at læse om idræt. Idræt skal opleves og helst som aktiv deltager. Idræt er bevægelse og symboler, dramatik og social samfølelse omkring en aktivitet i og uden for idrættens rum.

\section{Peirce og tegnet}

Netop derfor er idrætten også et godt sted at se nærmere på billedets natur. For hvad er egentligt grunden til, at billedmediet ikke indtager en mere fremtrædende placering i den historiske forskning? Hvorfor disse paradokser? Et svar finder vi hos amerikaneren Charles Sanders Peirce (1839-1914), der sammen med Freud, Saussure og Greimas hører til blandt det tyvende århundredes mest betydelige forskere inden for feltet. Peirce var uddannet kemiker, men hans egentlige interesse kredsede omkring filosofi, matematik, logik, semiotik og en række felter inden for disse områder. Selv om Peirce var nybry- 
dende inden for flere af disse felter, er det imidlertid først inden for de sidste 20-30 år, at hans forskning har vundet en bredere anerkendelse og er blevet fulgt op af bl.a. Umberto Eco.

Peirces forfatterskab er omfattende, men her er det især hans teori omkring tegn eller rettere tegnrelationer, der har interesse. Hvad er så tegn? Det er efter Peirces definition alle ting, der giver os associationer om andre ting. Tegn henviser til objekter, der kan sanses, eller som man kan forestille sig. Farven rød giver mig f.eks. opfattelsen af noget forbudt. Lyskurvens røde farve forbyder mig at køre frem, ligesom trafikkens forbudsskilte har rød som den gennemgående farve. Peirce arbejder med flere facetter af tegn og tegnrelationer alt efter, om man ser på tegnet i sig selv, forholdet mellem objektet for tegnet og det, han kalder interpretanten eller på relationen mellem tegnet og objektet. Ikke mindst det sidste er interessant, når vi arbejder med fotografiet og dets forhold til objektet dvs. det motiv, som vi fotograferer. For selv om vi mener at kende fotografiets natur, forstået som det at tegne med lyset, så er der langt mere dynamit $\mathrm{i}$ forholdet mellem motivet og det færdige resultat, der får nogle afgørende konsekvenser for vores arbejde med billedmediet.

For at forstå disse problemer må man skelne mellem tre typer af relationer mellem tegn og objekt, som Peirce opererer med. Der er ikonet, der ligner eller imiterer objektet, som det f.eks. er tilfældet med ikonet for svømning med svømmeren, der er på vej ud i bassinet fra startskamlen med begge hænder strakt bagud. Her finder vi også fotografiet, hvor lyset jo netop maler motivet på en lysfølsom sølvbelægning eller på de digitale kameraers CCD-elementer. Fotografiet som tegn ligner altså objektet i kraft af sin fysiske tilblivelse. Tegnet kan være et index, som viser hen til noget om genstanden (en pegefinger), fordi tegnet er fysisk forbundet til objektet og er påvirket af det. Men da fotografiet netop er blevet til i kraft af en fysisk påvirkning fra objektet via lyset, er det også et index. Endelig er der symboler, der er tegn i kraft af deres brug. Begrebet kat giver f.eks. kun mening, fordi vi anvender ordet og dermed kender meningen bag tegnet. Professor Peter Larsen i Bergen har for nyligt gjort opmærksom på, at det netop er fotografiets dobbelte status som ikon og index, dvs. som billede og pegefinger, der langt op i tiden har givet problemer for forståelsen af billedet. Helt frem til i dag har fotografiets status som index overtrumfet dets status som ikon og dermed undergravet fotografiet som en kunstart i sig selv. Til gengæld har netop dette forhold bidraget til at styrke fotografiets status som dokumentation, hvilket allerede skaberen af det moderne analoge fotografi William Henry Fox Talbot satte en tyk streg under, da han i juni 1844 begyndte at udgive serien $\gg$ The Pencil of Nature«, den første bog illustreret med fotografier. Egentlig er det først med fremkomsten af billedbehandlingsprogrammer som Photoshop, at der for alvor er rykket i vægtningen mellem fotografiet som ikon og index.

\section{Fra seniorfodbold $i$ Gråsten Boldklub til EM i Frankrig}

Ifølge Peirce er billeder som »rene likheder « ikke i stand til at informere. ${ }^{2}$ Fotografiet alene rummer ingen informationer, selvom fotografiet ligner motivet pixels for pixels. Arbejder man til dagligt med billedidentifikation og billeddatering, er man da heller ikke i tvivl om sandheden i dette udsagn. Vi er altså nødsaget til at berige fotografiet med informationer, hvilket kan 


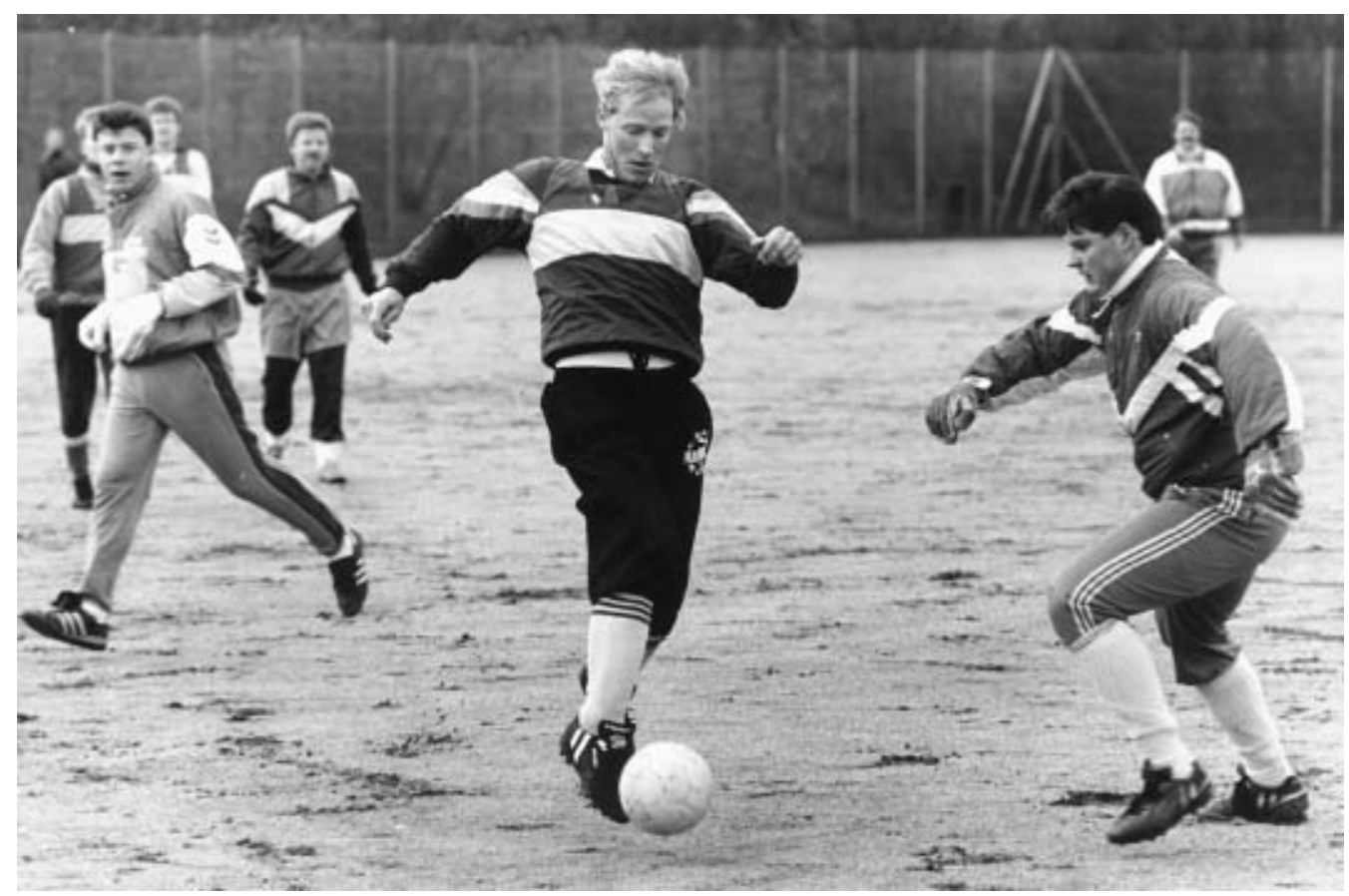

Gråsten Boldklubs seniorafdeling i kamp (Institut for Sønderjysk Lokalhistorie).

være en yderst tidskrævende og vanskelig proces. Identifikation af billedet er en appel til betragteren om at fortælle, hvorledes fotografiet står i forhold til tid, rum, personer og begivenheder. Identifikationen er altså en pegefinger, som peger i den retning, man skal gå for at komme til det objekt, fotografiet repræsenterer. Fotografiet er altså i stand til at bevise, at motivet har eksisteret, men det er ikke selv i stand til at fortælle beskueren, hvornår og hvorledes det er taget.

Kampen i Gråsten Boldklubs seniorafdeling var forhåbentlig god og spændende for såvel deltagerne som tilskuerne. Men dette fortæller fotografiet mig ikke. Det står heldigvis skrevet på bagsiden af fotografiet. Jeg ser kun en mand med en bold på vej frem mod fotografen og til højre en person, som tager afsæt for at nå manden med bolden. Heldigvis siger mine og an- dres erfaringer, at dette må være scenen for en fodboldkamp, men billedet fortæller mig det ikke. Selv om fotografen med brug af lys har malet virkeligheden på den lysfølsomme film med sit kamera således, at personerne på billedet punkt for punkt ligner de personer som en gang $1 \varnothing b$ rundt på banen, ja så fortæller billedet intet om personerne. Billedet som dokumentation er afgået ved døden og har sådan set aldrig for alvor eksisteret. I stedet skal jeg i mit arbejde med at identificere og analysere fotografiet finde en person med erfaringer, der $g \varnothing r$ det muligt at pege tilbage til motivet på det tidspunkt, da billedet blev taget. Dermed flytter fokus også over på relationerne mellem fotografen, fotografiet og betragteren. Den erkendelse er ikke uproblematisk for vores arbejde med idrætsfotografiet, hvad de følgende eksempler skal fors $\varnothing$ ge at anskueliggøre. 


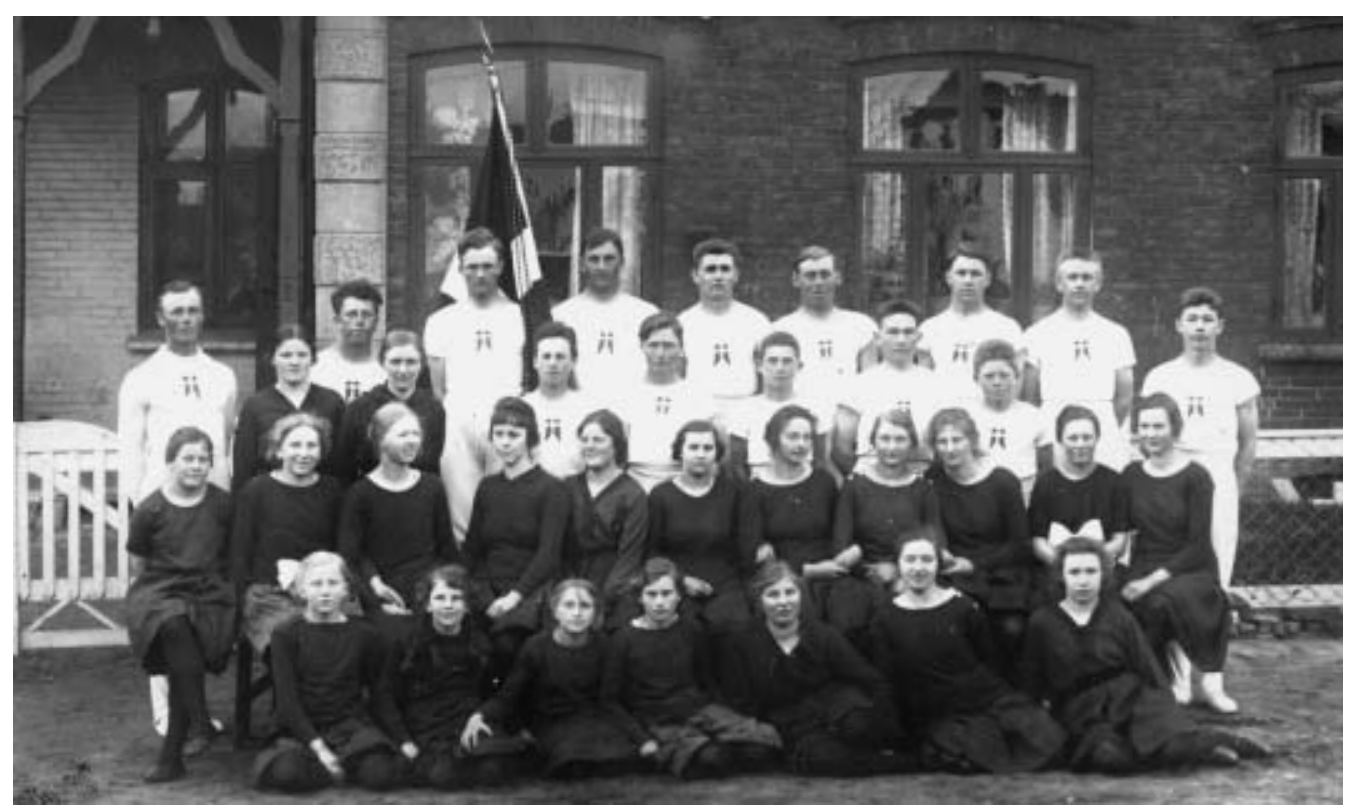

Gymnastikholdet i Bovlund 1920/21 under ledelse af laerer Valdemar Jensen (Institut for Sønderjysk Lokalhistorie).

Gymnastikholdet i Bovlund under ledelse af sognets nye danske lærer, Valdemar Jensen, blev fotograferet i 1920/21 umiddelbart efter Genforeningen. Flagning med Dannebrog var i Sønderjylland et stærkt signal til omgivelserne om, at man var dansk, og er det endnu i dag, selv om der langsomt er en opblødning på vej. I de antiautoritære 1970'ere var der ikke ret mange inden for især DIF-forbundene, som skænkede Dannebrog større opmærksomhed. Først fra slutningen af 1980'erne og med fodboldlandsholdets EM-sejr i 1992 svinger danskerne som aldrig før med Dannebrog ved større sportsbegivenheder. Men nu er det mere med Dannebrog som et hurraflag, en markering af en festlig begivenhed. Anderledes alvorligt var det for gymnastikholdet i Bovlund. Flere af mændene på billedet havde under første verdenskrig formentlig deltaget på fronterne i kampen for et fædreland, som ikke var de- res. Efter Genforeningen blev de mandlige gymnaster som her i Bovlund forsynet med bomuldstrøjer med splitflag for at markere den lykkelige begivenhed og det nationale sindelag. De kvindelige gymnaster, der ikke havde deltaget i krigen, måtte derimod vente endnu et par år før deres gymnastikdragter blev fordansket. ${ }^{3}$ Grænsekampen fortsatte efter Genforeningen og skærpedes i 1930'erne med mindretallets nazificering, der satte grænsen under et voldsomt pres. Betydningen af Dannebrog i den idrætslige sammenhæng har altså skiftet indhold, og i 1920 var det stærke sager, som fotografen forevigede i Bovlund. Selv om tegnet - Dannebrog - er det samme i dag, så har betydningen flyttet sig ganske radikalt, hvad man skal gøre sig helt klart, når man arbejder med idrættens billeder.

Helt galt kan det gå, hvis man ikke er en del af det fællesskab, der kender det uni- 


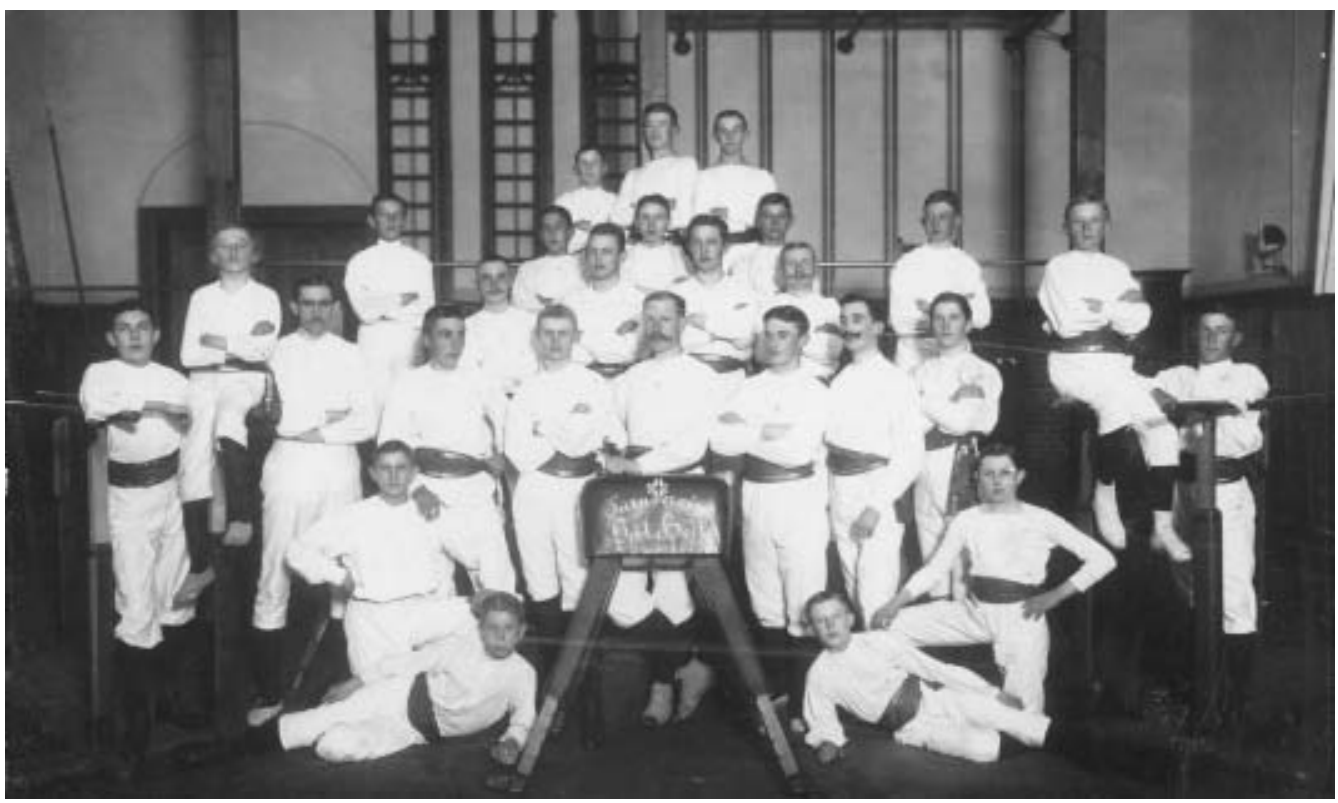

Turnverein Gut Heil i Haderslev (Haderslev Byhistoriske Arkiv).

vers af tegn, som fællesskabet anvender, eller hvis kendskabet til indholdet af tegnet er gået tabt. På billedet ses unge mandlige gymnaster med deres hvide gymnastikdragter og skærf i den tyske gymnastikforening »Turnverein Gut Heil« i Haderslev. Fotografiet blev for få år siden anvendt til en stor kampagne i Sønderjylland for indsamling af idrætsforeningernes arkiver og en styrkelse af forskningen i den sønderjyske idrætshistorie. I den forbindelse blev der trykt en plakat og en folder, hvor billedet indgik som et af to, hvor det andet forestillede en gruppe triatleter. Der gik imidlertid ikke længe, før forfatteren ad omveje fik besked om, at billedet var yderst uheldigt. Flere arkiver ville ikke sætte plakaten op eller dele folderne ud. Det var symbolet på plinten, der var årsag til problemerne. Gymnastikforeningens symbol blev opfattet som et nazisymbol eller i det mindste et tysk nationalt symbol. I virkeligheden er der tale om de fire F'er for Jahns valgsprog »Frisch-Fromm-Fröhlich-Frei«. Gut Heil blev stiftet i 1892 som en udbryder af Haderslebener Turnerbund, idet stifterne mente, at Haderslebener Turnerbund havde tabt gymnastikkens oprindelige mål, og derfor $\varnothing$ nskede en tilbagevenden til de jahnske ideer. Senere $\emptyset$ nskede foreningen også at prøve kræfter med den svenske gymnastik og nye discipliner som fodbold, rundbold og cricket. ${ }^{4} \mathrm{Da}$ billedet er taget før 1914, kunne det på ingen måde knyttes til tysk nazisme, som det var opfattelsen flere steder i Sønderjylland.

Det er imidlertid ikke kun betragteren, men også fotografiet selv, som har et problem med tid. Fotografiet har nemlig intet forhold til begrebet tid. Mange af os husker billedet af Preben Elkjær, der forlader banen med iturevne bukser og højre hånd på det let foroverbøjede hoved. Ja, billedet har nærmest brændt sig i vores bevidsthed. 
Alene bukserne fortæller, at noget alvorligt er gået forud, men hvad? Billedet har en forhistorie, men kun de, som oplevede fodboldlandsholdets succes i 1980'erne eller har sat sig ind i historien, kender den. For dem er billedet til gengæld også næsten blevet et ikon for landsholdets store sportslige præstationer i 1980'erne, som desværre kun rakte lige ved og næsten før målet, en plads i finalen. Danmark var med ved fodbold EM i juni 1984, der foregik i Frankrig. Her spillede Danmark åbningskampen mod værtslandet Frankrig, der var blandt favoritterne. Resultatet blev en flot kamp og et beskedent nederlag på et mål af Platini. Derefter blev det til en 5-0 sejr over Jugoslavien og en 3-2 sejr over Belgien, inden forventningerne var spændt til bristepunktet forud for semifinalen mod Spanien. Forventningerne om en nervepirrende kamp blev til fulde indfriet, og efter forlænget spilletid måtte man med cifrene 1-1 ud i en straffesparkskonkurrence. Sidste mand på dansk side var Preben Elkjær, men i det afgørende $\varnothing$ jeblik glippede koncentrationen, så det blev en spansk sejr på 5-4. Skuffelsen var ikke til at skjule hos de danske spillere, herunder også hos Preben Elkjær, der forlod banen med de famøse, iturevne bukser. Overskriften hed »Farvelkjær« den følgende dag i tabloidpressen. Først når man kender forhistorien, forstår man fotografiets stærke symbolværdi. Egentlig skal man nok også have oplevet kampen og den efterfølgende skuffelse for at forstå, hvor stærkt og præcist billedet ramte de danske følelser efter nederlaget i 1984.

\section{Landsmotionsstoevnet $i$ Svendborg}

Pierre Bourdieu er en af de forskere som med begrebet kulturel kapital har flyttet fo- kus over på relationerne mellem fotografiet og betragteren primært for at se på begrebet »smag «, dvs. evnen til at afkode tegn set i relation til social status og klasse. »Distinction « er på mange måder en meget fransk afhandling, vendt mod det franske klassesamfund, hvad Bourdieu også selv har vedkendt sig. ${ }^{5}$ Bogen kunne næppe være skrevet i Grundtvigs fædreland, men den peger helt afgørende på evnen hos den enkelte til at læse og skelne tegn. Men social status og klasse er ikke de eneste parametre, når det gælder evnen til at afkode tegn og besidde »god smag«. De mange idrætsgrene og deres udøvere udvikler deres egne tegn og opfattelse af god smag. Da Wladimir Salnikow ved de olympiske sommerlege i Moskva 1980 kom under 15 minutter i 1500 meter fri i tiden 14:58:27, var det ikke alene en sensation inden for svømmesporten. Det var også en ualmindelig smuk, æstetisk oplevelse af de helt store. Men kun for dem, som i kraft af deres engagement med svømmesporten kan »se«, hvor »let« og »ubesværet« han svømmede de 1500 meter, uagtet at der her var tale om en imponerende kraftpræstation.

Tid, sted, personer og begivenheder er relativt ukomplicerede elementer i fotografiet, hvis man ellers kan få billedet identificeret. Værre er det at fortolke de betydninger, der i modsætning til Dannebrog ikke er alment tilgængelige eller kun deles af en mindre del af befolkningen.

På billedet ses en række inriggere liggende på grønt græs i en halvcirkel. Yderst til højre i billedet ligger outriggere på græsset. Området er hegnet ind og til venstre ses telte, $\varnothing \operatorname{lvogn}$ og tilskuere. I baggrunden ses vandet, en bådebro og Dannebrogsflag. Vedlagt billedet er der oplysninger om, at det er taget den 30. august 2003 på landsmotionsstævnet i Svendborg. Billedet stammer altså fra Dansk Forening for 


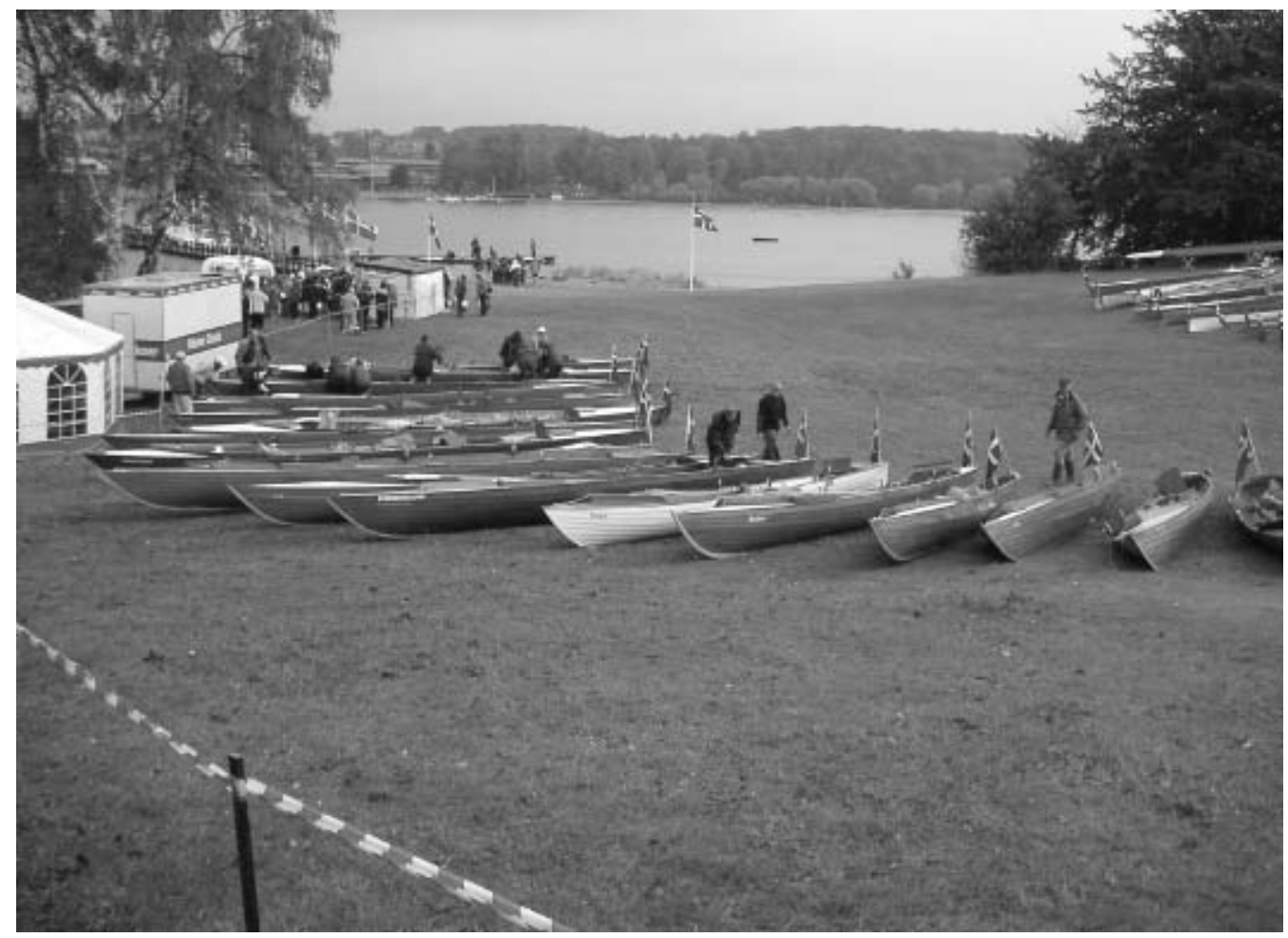

Inriggerbåde ved landsmotionsstavnet i Svendborg den 30. august 2003 kl. 7.34.57. I kraft af den digitale teknologi kan man med brug af EXIF skaffe informationer, som det ikke var muligt med det analoge kamera. Men det er teknikken bag kameraet, der registrerer disse informationer. Selve fotografiet har intet bud på det pracise klokkeslat. Foto: Lis Nielsen (Dansk Forening for Rosport).

Rosports årligt tilbagevendende landsmotionsstævne, en idrætsbegivenheden inden for rosportens breddeidræt. Her mødes aktive roere for at ro, møde roere fra hele landet og deltage i de sociale og idrætslige arrangementer, der er knyttet til stævnet.

Men billedet er også meget symbolladet. Det afgørende er ikke kun splitflaget agter på bådene. Det er hele kompositionen med de mange både - liggende side ved side der er interessant. Inden for rosporten er motivet med flere både på land taget fra forskellige vinkler nærmest et genrebillede. Typisk tages billederne på en weekendtur eller en ferielangtur, hvor bådene træk- kes op på strandkanten, hvor de ligger, indtil man fortsætter den følgende dag efter overnatning i telt. I dette tilfælde ses 17 inriggerbåde, men typisk vil der være tale om 2-5 både afhængigt af deltagerantallet på turen. Motivet knytter altså an til den del af breddeidrætten inden for rosporten, hvor der ikke alene er tale om ren motion, men hvor motion, naturoplevelser, fritid, ferie og ikke mindst et tæt socialt samvær er knyttet næsten ubrydeligt sammen til et hele. Det sidste dyrkes ikke blot i klubhuset, på standen eller i teltet. Rosporten er en af de få sportsgrene, hvor man kan tale sammen under udøvelse af idrætten. Idræt- 
ten giver altså rig lejlighed til at vende alt fra vindretning og vindstyrke til lokal sladder og verdenssituationen.

For mange roere rummer billedet derfor et koncentrat af de positive oplevelser ved roningen, de mange timer på vandet, hvor snak, roning og naturoplevelser går op i en højere enhed, men også ferie- og weekendturene, hvor bådene anvendes som et transportmiddel til at bringe roerne til nye steder og oplevelser. Her suppleres idrætten med fælles oplevelser på strandkanten, i teltene og i andre roklubber. Billedet af bådene er derfor et »smukt« billede for en aktiv roer. Ikke blot fordi det er godt rent teknisk, men fordi der er mange både fra mange roklubber samlet på et sted. Det fortæller om en stor begivenhed med mange deltagere, stor roaktivitet og et stort socialt fællesskab. I én henseende er billedet dog lidt kunstigt. Robåde ligger normalt ikke på græs langt fra strandkanten, men i strandkanten lige netop så højt oppe, at bådene ikke driver ud med højvandet. Derfor er der formentlig også nogle, som vil hævde, at billedet ikke er helt godt. Bådene skal ligge i strandkanten.

Som sådan taler billedet til mig. Det genkalder min erindring. Og jeg mindes gode stunder med min idræt. Men hvad er det nu det? Der kommer nu noget andet ind over min analyse og vurdering af billedet. Roland Barthes skriver i sin personlige og ikke altid lige tilgængelige afhandling »Det lysende kammer « følgende: $\gg I$ dette triste $\varnothing$ de hænder det pludselig, at et og andet foto fanger mig; det opliver mig, og jeg opliver det. Sådan bør jeg altså benævne den tiltrækning, der får det til at eksistere: en oplivelse. Fotoet selv er på ingen måde livagtigt (jeg tror ikke på »levende« fotos), men det opliver mig, og det er, hvad enhver oplevelse $g \varnothing r \ll .{ }^{6}$ Barthes taler videre om et »punctum «, der også giver det lille stik, som prikker til mig. ${ }^{7}$ Men er dette lille stik eller prik ikke en ideologisk effekt $i$ althussersk forstand? Althusser taler om ideologi som genkendelse af evidenser, over for hvilke vi højt eller stille udbryder: »Det er helt klart! Sådan forholder det sig! Det er helt rigtigt! $\ll^{8}$ Genkender jeg ikke mig selv som roer i dette billede som i mit spejlbillede? Anvender jeg ikke netop så uforholdsmæssigt mange linier og ord på netop dette billede, fordi billedet giver mig det lille stik, en erindring om det forgangne og en del min liv? Er det ikke netop denne samhørighed mellem billedet og forfatteren, der har udpeget dette billede blandt mange andre? For med valg følger også fravalg. Genkendelse er nemlig også forbundet med misgenkendelse. Eller er sandheden blot, at jeg har en aktie i et bådværft og ønsker at fremme salget? Faktum er, at mange idrætsbilleder er blevet vurderet, inden valget faldt på netop dette og de $\emptyset$ vrige billeder i artiklen.

\section{Mellem videnskab og ideologi}

Men genkendelse er en ideologisk effekt, ikke en videnskabelig, der skal skabe ny erkendelse. Genkendelse kan i princippet ikke blive videnskab. Alligevel har jeg valgt at bringe netop dette billede $i$ et videnskabeligt årsskrift, der $\varnothing n s k e r$ at formidle ny erkendelse. Videnskaben synes let at forsvinde som sand mellem fingrene, netop som man forsøger at forstå billedet og dets betydning.

Intet er mere velegnet til at formidle og beskrive idrætten og dens væsen end fotografisk materiale som billeder og film. Det kan beskrive begivenheder og stemninger, som kun de færreste kan formidle på skrift. Men samtidig er det fotografiets akilleshæl, at det ingenting dokumenterer. Læseren må tro på forfatteren, tro på, at billedet 
faktisk er fra landsmotionsstævnet 2003 i Svendborg. Billedet er end ikke i stand til at dokumentere sig selv. Hvordan blev billedet til? Er billedet arrangeret? Hvem var fotografen? Hvilken linse blev der anvendt, og er det siden blevet beskåret? Dermed bliver personen bag analysen inddraget og involveret $\mathrm{i}$ erkendelsesprocessen $\mathrm{i}$ et helt andet omfang end normalt $i$ en historisk analyse, hvilket bringer historikeren ind $i$ et spændingsfelt mellem ideologi og videnskab. Hans Bonde skriver i sin disputats: »I idrætshistorien er billedanalyse særligt væsentlig, da idræt fundamentalt handler om fascination ved selv at udføre bevægelser eller se andre gøre det, hvilket har affødt et meget stort og centralt kildemateriale «. ${ }^{9}$ Jeg kan ikke være mere enig, men jeg tvivler på, at de erkendelsesmæssige problemer med brug af idrætsbilleder alene er løst med kildekritiske analyser.

\section{Noter}

1. Om forholdet mellem tekst og billede på Internettet se Niels Finnemann (2005), særlig s. 165-170.

2. Peter Larsen (2004) s. 63.

3. Inge Adriansen (2002) s. 19.

4 Arkivar Uffe Barsballe Thyssen: »Gymnastikkens brydningstid og Turnverein Gut Heil« på www. isl.dk.

\section{Litteratur}

Inge Adriansen: »Idrætten i det nationales tjeneste « I: Idrætshøjskolen i Sønderborg 50 år. Sønderborg 2002, s. 5-29.

Inge Adriansen: »Nationale symboler i Det Danske Rige 1830-2000« bd. I-II København 2003.

Louis Althusser: »Ideologi og ideologiske statsapparater « Århus 1983.

Roland Barthes: »Det lyse kammer. Bemærkninger om fotografiet « København 1996.

Axel Bolvig: »Med passende ændringer. Historisk metode i fokus » I: Tove Hansen: »Sølv og salte. Fotografi og forskning København 1990, s. 225232.

Hans Bonde: »Niels Bukh. En politisk-ideologisk biografi« bd. I-II. København 2001.

Pierre Bourdieu: »Distinction. A social critique of the judgement of taste «. 1979/2002.
5. Pierre Bourdieu (1979/2002) s. xi.

6. Roland Barthes (1996) s. 30.

7. Roland Barthes (1996) s. 38.

8. Louise Althusser (1983) s. 50.

9. Hans Bonde: »Niels Bukh. En politisk-ideologisk biografi $\ll$ bd. I, s. 41.

Broady Broady og Mikael Palme: »Pierre Bourdieus Kultur- och Utbildningssociologi. En introduktion «. Stockholm 1984.

Peder Voetmann Christiansen: »Charles S. Peirce: Mursten og Mørtel til en metafysik« Roskilde 1988.

Niels Finnemann: »Internettet i mediehistorisk perspektiv« Frederiksberg 2005.

Kim Furdal: »Fra billeder til makulatur« i: Fortid og Nutid 2004, s. 42-57.

Bjarne Ibsen: »Frivilligt arbejde i idrætsforeninger« Odense 1992.

Peter Larsen: »Album. Fotografiske motiver « København 2004.

Charles Sanders Peirce: »Semiotik og pragmatisme« København 1983. 